\title{
RIGHT TO THE CITY AND RIGHT TO THE NON-CITY: NEO-EXTRACTIVISM AND SOCIAL MOVEMENTS IN SOUTHERN EUROPE
}

\author{
CARLA PANICO ${ }^{1}$ \\ ${ }^{1}$ University of Coimbra, Centre for Social Studies (CES), Largo D. Dinis, Apartado 3087, 3000-995 \\ Coimbra, Portugal. ORCID: 0000-0002-2810-1458, Email: carlapanico@ces.uc.pt
}

ABSTRACT: This text aims to propose a reflection on the phenomenon of so-called touristification within the geographical area of Southern Europe concerning two points: how the processes of production of space that go under this name can be placed inside of the framework of the neo-extractive processes and how social movements against tourism may eventually resonate with the perspective of political ecology.

The hypothesis is that this typology of accumulation processes responds to a certain colonial rationality of capitalist exploitation within a specific area of the Global North - Southern Europe - starting from the global economic crisis of 2008, which I assume as a historical period characterized by specific forms of production of space (Lefebvre 1974) and specific social movements - the anti-tourism movements and the environmental struggles.

KEYWORDS: touristification, Southern Europe, Political ecology, right to the city, extractivism

\section{ABOUT EXTRACTIVISM AND NEO-EXTRACTIVISM IN THE PRODUCTION OF SPACE}

One of the theoretical categories on which my analysis will be based is that of 'ex- 
tractivism': in particular, on the idea that the forms of action of capitalistic-colonial rationality on the value of territory and the production of space are specifically continuous and contemporary forms of original accumulation.

This concept, which refers in the first place to those economies that are based on the predatory withdrawal of the natural resources of the territories, has recently met, starting from the South American debate (Gago 2015; Zibechi 2016), an extension of its field of application to the domains of finance and urban economics (Gago \& Mezzadra 2015; Mezzadra \& Neilson 2013, 2015), up to being interpreted "as part of the process of 'accumulation by dispossession' (Harvey 2010), characteristic of the period of domination of financial capital.” (Zibechi 2016)

The concept of extractivism, in this sense, refers, in the way I intend to use it, to that category of analysis of the so-called 'accumulation for dispossession' that David Harvey used to describe the economic scenario of the global financial crisis. In Harvey's theory, these forms of extraction indicate a new phase - or rather a sort of 'return' - capitalist exploitation: no longer - and not only - capitalism as a power relation that insists on a biopolitical dimension - that is, of the reproduction of life valued by capital; but also capitalism as a purely extractive mechanism, which is placed 'outside of life itself' and no longer needs to encourage its reproduction.

In this sense, Harvey interprets the massive process of impoverishment of the US middle class, in particular the way in which this process originated and has strongly impacted the urban dimension since the financial crisis was immediately manifested as a real estate crisis in that part of the world.

Assuming this perspective of analysis, however, I would like to specify its limits and scope better. The theme of extractivism as a category of analysis of a specific mechanic of the functioning of capitalist power does not assume, from my point of view, the role of a periodizing caesura that characterizes in the absolute a 'new' phase of global exploitation.

First, we must always consider that we are not faced with a paradigm shift, since mining practices continue to be flanked by a "productive" dimension of power- in the Foucaultian meaning: they are simply applied on different groups subjected to such an exploitation regime. Furthermore, as pointed out by Miguel Mellino (2014), by discussing Harvey's text so far quoted, even if we assume that we consider this extractive dimension of Capitalism as an innovation, in reality it is a novelty only within the space of the global North.

From the point of view of a postcolonial Marxist critique, in fact, Mellino underlines how the continuity of practices of accumulation and dispossession, or extractivism on human and natural resources - completely characterizes the history of capitalism in the colonial space: that is, capitalism has, from its origins, a necropolitical (Mbembe 2003) tendency to accumulate value by extracting it from living labor and from the territory, even at the cost of the destruction of life and nature, when these resources are in abundance.

What I would like to emphasize is that the category of extractivism, which lends itself well to the analysis of certain capitalist enhancement processes that have occurred - always following Harvey - within the capitalist paradigm of the global eco- 
nomic crisis, must always be read within a kind of cognitive decentralization, as a category of postcolonial capitalism.

In a rather comparable analysis perspective, Sandro Mezzadra (Mezzadra 2008) makes precise reference to the processes of original accumulation as phenomena not only 'of antiquarian interest', but, on the contrary, constantly present and re-proposed in different phases of capitalist development. In particular, Mezzadra traces exactly a colonial genealogy of these phenomena: in the global North, capitalist development was associated with different phases of productive organization that constituted a sort of necessary evolution of the more appropriately extractive phase - specifically, the 'liberation' of living labor which turned into wage labor as a pivot point for advanced capitalism coming out of the accumulation phase; in the colonies, on the contrary, these different exploitation regimes had always been coexistent with pure extractivism mechanisms - both in labor regimes and in relation to natural resources (Visentin 2013).

My initial interpretative hypothesis is that the global economic crisis has represented a specific moment of particular intensification of the use of this form of colonial rationality of the capitalist organization even within the global North: capitalism, even in the Global North, is it is restructured through the application of techniques learned and developed previously only in the colonial space.

In other words, with the rapid impoverishment of the middle classes in specific areas of Europe and the United States, the authoritarian tendency towards government techniques in the same areas has affected both subjects and places. In the first case, in the form of restrictions on social rights and welfare. In the second case, through the privatization of the territories, the 'sale' of the places and the affirmation of new urban paradigms (Brenner, Marcuse, \& Mayer 2012).

\section{WHICH SOUTH? ABYSSAL LINES WITHIN EUROPE}

What I would like to try to add is that the reproduction of extraction practices within the global North is not at all uniform and that specifically the exercise of what I have so far called colonial capitalist rationality unfolds through space producing - or reproducing - South in the global North. In other words, using a concept coined by Boaventura de Sousa Santos, the application of this neo-extractivism - that is, this mixture of colonial extractivism and biopolitical government techniques - traces and 're-traces' abyssal lines (Sousa Santos 2007) in the global North.

The metaphor of the abyssal line, due to its close connection with the theme of space production, seems to be particularly effective for introducing and qualifying the area on which I would like to apply my analysis. In fact, the abyssal line marks North and South not only as geographical definitions, but mainly as relations of power - and emancipation - inscribed in space, or even, in the production of the same.

The 'South' demarcated by the abyssal line, therefore, is produced as absence and otherness, as a territory defined by the hegemonic categories coined on the other side of the line.

Within this framework, my analysis focuses on a specific 'relational south' within 
the global north, defined by a complex network of abyssal lines: Southern Europe.

This specific area of the continent is historically surrounded by a combination of representations and discourses - in a model that we could define as 'Orientalist' (Said 1978) - on one's own otherness compared to the rest of the continent that we can trace back at least to the nineteenth century; on the other hand, the representation plan is intertwined with an economic imbalance between the two areas of the continent which, at least throughout the 20th century, has made Southern Europe a relatively low-cost migrant labor pool for the most 'developed' capitalist areas of central and northern Europe.

This deliberately rather vague framing of the question of Southern Europe is necessary to understand a point: the abyssal lines that are drawn by specific modes of articulation of power on which we want to dwell are not invented or created by a precise choice of global capitalism; on the contrary, what perhaps should be emphasized in general in the metaphor of the abyssal line is how it functions, very often, by stratification and interlacing, rather than as a break.

I mean, with this, that the production of a South inherent in the metaphor of the abyssal line works particularly well in the case of the re-production of a space on the basis of multiple levels of production of the alterity of this place; levels that are placed both in the plane of discourses and cultural representations and in that of economic power relations.

My analysis focuses on a specific articulation of the North-South relationship within Europe - that is, that which, during the global economic crisis, focused on the different distribution of debt, creating an economic dichotomy and a specific apparatus of representations that have identified Southern European countries as PIGS; or, in other words, a combination of economic subordination and discourses that represented these places and the populations that inhabit them as anthropologically guilty and materially in debt: this process and its colonial framework were perfectly defined as the 'calibanization' of Southern Europe in the financial crisis discourse (Ervedosa 2017).

Both aspects of this reproduction of the South draw on an extensive archive of ethnographic representations and economic relations which, as we mentioned earlier, constituted the founding basis capable of reversing them. At the same time, this joint of abyssal lines has, in my opinion, permitted a specific application of that neo extractivism of the colonial matrix that we have described so far, and which has been applied to the transformations of the European labor market as to the production of space.

How the typology of colonial rationality that we tried to describe in the first paragraph - i.e., an intensification of the mechanics of capitalist exploitation that intertwines extractivism and biopolitics in the global north as a result of the economic crisis - interacts with the re-production of this specific South?

What spaces are produced and which battles for places are at stake in these power relations exercised in space?

To develop this articulation between space production and neo-extractivism in contemporary Southern Europe, I would like to try to dialogue two areas of political 
reflection and academic research that focus on the processes of 'predatory sampling of the natural resources of the territories': urban studies on 'turistification' and political ecology.

Both of these approaches have the characteristic of being not only corresponding to research groups and schools of interpretation, but they are strictly resonant and particularly stimulated by recent social movements - as we shall see, in both cases, particularly located in southern Europe.

\section{HOW SOUTHERN EUROPE BECAME TURISTIFICATED}

Urban planning studies on tourism, or rather on the way in which the tourist economy impacts and changes the urban fabric, have become widespread in Europe in recent years.

The aspect on which I would like to dwell in this paragraph is how the phenomenon of the so-called turistification can be inscribed within the neo-extractive paradigm of which we have spoken and how it acts - with a colonial rationality - in the dynamics of reproduction of South to the within the European area.

The first point is to identify how the typology of phenomena in question is inscribed in the relationship between economic and urban, or in the articulation between contemporary capitalism - and its class dimensions - and the production of space.

The use of the term 'turistification' is based on the notion of 'gentrification' - which already contained exactly the problem of spatial and urban articulation of economic reasoning - and specifies its use.

The two concepts designate two processes of urban extractivism (Salerno 2018) with similar characteristics, but they are not at all superimposable. Both are processes related to the commodification of the urban, however, the so-called gentrification can constitute only one aspect or part of the process of turistification; on the other hand, gentrification can be strongly driven by tourism transformation processes, but it is not necessarily dependent on it.

In both cases we are faced with a population substitution; in both, in addition, the so-called rental gap is at the center of this replacement: that is, an economic differential between the potential level of income of a given area of the territory and the level that is currently achieved through the use of the same territory.

This rent gap becomes much more valuable when the area under examination has suffered a collapse in its real estate and commercial value, as this attracts capital investment in view of a particularly large profit margin.

This, however, occurs in ways that can be very different, and that in the case of turistification have their own characteristics.

First, gentrification normally determines 'the replacement, within a given area, of less well-off social classes with more affluent ones, whose common characteristic lies however, in the stability of the settlement' (Salerno 2018). The intervention of tourism, instead, produces a replacement of a resident population with an 'intermittent', which resides in the territory for relatively short periods. This causes a replacement 'of the residential area in itself with new forms of crossing places' (Salerno 2018), or 
in other words, a significant variation of the centrality of use value of the territory in favor of the exchange value.

Moreover, although at the bottom of both extractive forms there is a tendency to expel and displace a specific population - belonging to a lower social class or to a more vulnerable social group than those of the following population - the case of turistification does not concern only and exclusively the housing issue, since this phenomenon also impacts trade strongly.

Once the 'rent differential' of a territory has attracted the investment of capital, in fact, this transformation creates a chain effect on the type of services and commercial establishments that develop in that particular area. In the case of tourism, the presence of accommodation facilities for this nonresident population - b\&b, hotels, airb$\mathrm{nb}$ - produces the growth of commercial establishments aimed at new customers, to the detriment of the commercial offer for 'settled' inhabitants. The latter will always be less ideal tenants and able to compete to remain in that particular area, once the commercial offer has attracted more tourists.

A further difference to be clarified lies in the relationship between transformation and conservation of space. The processes of gentrification, in fact, are characterized by a transformation of the use of the territory that can also foresee the destruction of what was there before - as an urban example, in conjunction with a massive displacement of the population, a whole neighborhood can be razed and rebuilt.

On the contrary, in the processes of touristification there is the need to preserve the territory, immobilize it in an image that is usable and equal to itself to 'sell' it in a new guise; this concerns both the 'natural' and the anthropized landscape - in the urban case, once again, these processes are defined as 'patrimonialisation' and 'museification' of the historic city centers (Salerno 2018).

This reconstruction of how turistification is exercised as a form of neo-extractivism - based on the definition of this mechanism and its novelty points described in the first paragraph - is necessary to register these processes within an effective colonial rationality of the production of space. Several texts of studies on tourism are recently focusing on highlighting the usefulness of this category of analysis.

Already in a 1989 text, in fact, Crick defined tourist economies as intrinsically connoted by a 'colonial' character, meaning, in his case, this description as that of a type of economy that makes conspicuous consumption of 'accumulated' resources in the time his distinctive trait (Crick 1989).

The recent text by Salerno (2018) also comes to the same conclusion, in which the 'colonial' character of tourist economies is evidenced by a detailed analysis of five aspects of the articulation of this dynamic that I try to briefly summarize: the economic dependence produced on the territory in question, due to the concentration of the flows of capital in a monoculture; the intensive exploitation of resources that tend to run out - in this case, the territory itself; the 'impoverished development', or rather concentration instead the redistribution of wealth; the disintegration of the social fabric on which this is exercised economic reason; finally, the tendential increase in authoritarianism in land management. The colonial rationality that characterizes the turistification, in short, is characterized as a way of organizing the economy of a place 
in function of an external market.

The extractive paradigm of a colonial matrix that marks the return of new forms of 'accumulation for dispossession' and that defines the tourist economies that we have described so far interacts with that process of re-production of the South that occurred around the abyssal lines which cross Europe. This dynamic is a non-linear interaction, but I would like to propose some starting points from which to try to investigate it.

First of all, the overall intensification of the phenomena of economic transformation and urban planning due to tourism is not at all analyzable as a uniform event nor does it correspond in univocal way to a simple quantitative increase of tourism in Southern Europe.

What can rather be observed in European space is a mutation in the direction and especially in the flows of tourism itself, which produced, in a differentiated manner, the presence of a new social actor in the articulation of the city space - i.e. Lisbon - or one simple intensification of an already validated presence - i.e. Venice.

In particular, due to the impoverishment of the European middle class, tourist flows have undergone a major change that has significantly reduced the spread of holidays and travel outside the continent, in favor of domestic tourism.

In this process, Southern Europe presented some optimal characteristics to become a destination attractiveness of new domestic tourism; in the first place the coexistence of landscape resources in the non-urban spaces - the optimal sea and climate which make the Mediterranean 'the new tropics' - and historical-cultural in urban ones - the cities of art; secondly, the relatively low cost in areas with 'new' tourist potential, comparing with the cost of Northern Europe or of the 'exotic' tourist locations outside Europe.

Furthermore, I would like to suggest that the way in which the economic crisis is articulated as a real estate crisis has greatly favored the development of these processes.

In countries like Portugal, Spain, Italy and Greece, the massive impoverishment of the middle class has occurred, translated also in the inflation of mortgages, which caused that many residents lost their homes or, more simply, they became not very competitive actors on rental market, based on the mechanism of greater attractiveness of short-term rents than we have tried to describe previously. What I would like to argue is that the economic crisis has largely favored, in Southern Europe, the production of the 'rental gap' that we have just now seen to be at the base of the processes of urban extractivism, favoring, in fact, the change of the connotation of the use of certain areas, both in favor of new populations and of the new offer commercial aimed at them. ${ }^{1}$

As a last element, I would like to add that the tendential increase in unemployment rates in the aforesaid regions and in particular in the poorer areas, had a strong weight on the process of "impoverishment of the social fabric" mentioned above. In fact, according to Salerno, this process generates "a passive civil society whose main expectation of wealth is determined by rents, thus reducing social creativity “. Indeed, in the social breakdown produced by the employment crisis, tourism was identified as

\footnotetext{
${ }^{1}$ A paradigmatic case would be that of the AirBnb phenomenon. (see Gainsforth \& Sarah 2019)
} 
the only possible source of employment and income for the native populations.

The 'impoverished development' typical of the colonial brand of the tourist economy has been translated into a real statement without alternatives: the development of tourism as a vehicle for one possible economic and social salvation - completely individual and competitive - has become the only one possibility of alternative work to emigration from the territory, although at the cost of 'exhaustion' of the territory itself. This contradiction between development and territory is, in my opinion, at the base of the phenomenon of turistification, and constitutes the problematic node, critically highlighted from birth and ever greater spread in the South of Europe of social movements against the turistification.

Social movements arose in opposition to tourism, as well as providing a sort of mapping of the urban transformations in progress, have constituted a real new generation of urban social movements in areas of tendential deactivation of political activism.

As emphasized by Neil Brenner, Peter Marcuse, Margit Mayer (2013, intro), the effects of global economic recession are dramatically intensifying the contradictions on which urban social movements are called to confront, putting them to immediately elaborate claims concerning the unsustainability and the tendency to destroy the 'neoliberal forms of urbanization':

Equally important is the question of how this crisis has provoked or constrained alternative visions of urban life that point beyond capitalism as a structuring principle of political-economic and spatial organization.

Capitalist cities are not only sites for capital accumulation strategies; they are also arenas in which the conflicts and contradictions associated with historically and geographically specific accumulation strategies are expressed and fought out. (Brenner, Marcuse, \& Mayer 2013)

Although with enormous peculiar differences in the processes that have invested every single territory, many cities in Southern Europe have, in recent years, seen the emergence of social movements opposed to the turistification. These movements have particular roots in Spain, which, among the countries of Southern Europe, was also the one most characterized by the spread of radical movements organized on the theme of the housing, following the estate crisis - in particular, the Plataformas Afectados de la Hipoteca (PAH): these networks of activism and mutualism, in the Spanish case, were the first direct activators of movements against tourism, through the convocation of demonstrations and assemblies that connect more claims on the collective use of urban space.

These metropolitan social movements carry forward the overall claim of 'Right to the city', that is not only to the house, but also to the possibility of participating in the processes of urban space production: Among the themes claimed, in the Spanish case, there are the application of the Ley de Dependencia [Law for the autonomy of people in situations of dependence, approved by the Zapatero government in 2006 - ndt], the right to a worthy job, the right to a public transport system that does not marginalize parts of the city. 
Following a series of international meetings proposed by the Spanish realities in the last two years, in April 2018 the founding Manifesto of the SET network commenced - Southern Europe against turistification. ${ }^{2}$ A network of cities ${ }^{3}$ and grassroots experiences, with a fort rooting in the Iberian peninsula, which aims to address the effects of the extension of urban tourism industry.

In the nine points of common reflection among all the cities that are listed in the manifesto, we find the problem of the increase in rents and the consequent precariousness of the right to housing; the transformation of the shops for the tourist offer to the detriment of the local population; the limitation of access to public space for the inhabitants, as streets and squares are always more congested; the saturation of public transport; the economic 'monoculture' which creates dependence of the territory on tourism; the precariousness of the working conditions of the population employed in the tourism industry; the pollution and the high consumption of environmental resources exhaustible; the constant increase in the construction of invasive infrastructures for the territory; Lastly, the 'trivialization of the territory', with the tendency of transforming places into 'thematic parks' for the use and consumption of tourists.

As can be seen from this short list, the claims of these anti-tourism movements are very varied and invest the subject of the rights of local populations in very different aspects a take part in the choices concerning the production of space.

The problem of extractivism, also declined in the political sense of the tendency to shift power to decide on the territories in the hands of economic actors outside the territories themselves, is part of the municipality reflection of these movements. The organizational form of the network of rebel cities can be defined, in the words of Boaventura de Sousa Santos, a form of "connection between South and South" (Santos 2007), or alliances between movements and subjects that are found to be "on the other side of the abyssal line" without these relations being mediated by the intermediation of the North.

\section{MAPPING CONFLICTS FOR SPACE: WHERE DOES THE RIGHT TO THE CITY END?}

Finally, I would like to add a critical element with respect to the picture I tried to trace so far, and which frames tourism in Southern Europe and the social movements that it is opposed to in the interpretative framework of extractivism and its colonial rationality.

As I tried to reconstruct, extractivism - also based on the recent South American readings of this phenomenon (Gago \& Mezzadra 2015) - also implies a strong exploitative dimension mass of natural resources (Gorz 2003).

If this dimension is very present in the debate on extractivism and if, at the same time, all the definitions of the phenomenon of turistification undoubtedly include the problem of exploitation of the non-urban or non-metropolitan territory, however, we

\footnotetext{
${ }^{2}$ The founding cities of the network are: Venice, Valencia, Seville, Palma, Pamplona, Lisbon, Malta, Malaga, Madrid, Girona, Donostia / San Sebastian, Canary Islands, Camp de Terragona, Barcelona.

${ }^{3}$ The manifesto is available in Italian, Spanish and Portuguese at: https://youtu.be/nnDoK6vz7sM
} 
must find that, in fact, studies on the tourism remain strongly marked inside the frame of the studies of urban planning as well as social movements against touristification remain, fundamentally, metropolitan movements.

The 'non-city' - I will try briefly below to explain why I use this phrase - seems to be the great absent in this picture, although it is space of accumulation processes very violent and, in the case study we examined, that is Southern Europe, very much evidently a field for the exercise of massive tourist processes. From the province of Almeria in Spain to the Greek Islands, from the Algarve in Portugal to large areas of Southern Italy - the Salento, in the south of Puglia, for example - the non-metropolitan territories have been the subject of a very strong tourist transformation, especially as relatively less rich areas than the rest of the countries in which they are located and therefore excellent candidates for becoming tourist destinations not too much expensive, based on the phenomenon I tried to describe in the previous paragraph.

My intention is not to repeat a traditional theoretical divide between city/nature or, alternatively, city/countryside - as two contradictory aspects of capitalist and capitalization processes of space production, because the two terms are clearly relational and interconnected.

A large literature of urban studies has highlighted the importance of this relationship in the process definition of urban and non-urban space until the definition of $\mathrm{Na}$ ture Metropolis is coined (Cronan 1991) to underline the fundamental role of the relationship with the surrounding space in the birth and structuring of the city.

At the base of this approach it seems to me that we can trace the concept of urban society, which Lefebvre coins in 1970 to "give name to the post-industrial society, that is the one that is born from industrialization"(Lefebvre 1970). This new society that arises "From the complete urbanization of the world" is not just the extension in space of what already was intended as a city; instead, it is a process in which "the noncity and the anti-cities will be conquered by the city, penetrate it, make it explode, and consequently extend immeasurably, resulting in the urbanization of society, in the urban fabric that covers the remains of the city before the industry "(Lefebvre 1970). In other words, the characteristics of urban society, or post-industrial, predominate as much on the countryside as on the city itself, to the point that the classical opposition between the two concepts of space no longer makes sense in the continuum of the urban fabric ${ }^{4}$.

However, previously, Lefebvre had questioned the contradiction city/countryside in partially different terms, and which provide other interesting ideas for our analysis. In Right to the city (Lefebvre 1968), the problem of the relationship between nature and culture is posed in terms of that between city and country; this articulation is identified in three terms: rurality, urban production, centrality. The relationship between these aspects, according to Lefebvre, varies with the variation of production relations; although he undoubtedly recognizes the centrality of the urban in the

\footnotetext{
${ }^{4}$ It is in this context that the analyzes of Negri and Hardt are situated around the theme of the metropolis, according to which the state current "the metropolis is for the multitude what the factory was for the working class," as "space of the common, of life in common, of the sharing of resources, of exchange goods and ideas" (Negri and Hardt 2010).
} 
capitalist production relationship, from the high side the confusion that the borders between countryside and city generate still attracts his attention. The city-country contradiction, according to Lefebvre should not be overcome in a "generalized confusion in which the country is lost inside the city and the city absorbs the campaign by losing it". In reverse, urban life itself contemplates "special mediations between city, countryside and nature. So is the village, whose relationship with the city, historically and currently, is far from being completely known.”

What I would like to suggest with this reconstruction is that the question of the centrality of the urban in the processes of capitalist accumulation and social reproduction - set by Lefebvre and variously developed in the subsequent literature - has decisively oriented the debate on turistification and its extractive role. Without questioning the importance of the metropolis in the current configuration of capitalist power and in the possibilities of autonomous organization of the social movements, it remains to ask: what becomes of what is not city?

While fully assuming the deconstruction of the Manichean binarism city-countryside or city-nature, it still seems important what told by Lefebvre about the contradictory nature of this relationship, and especially about the galaxy of other forms of space occupation that are produced in the mediation between these two principal: the village, the rururban.

Forms of accumulation for dispossession and extraction of territories that are directly or indirectly connected with the tourist economy occur, within the 'South' of which we are occupying, even in non-metropolitan areas - that is, not within cities, but in those spaces of mediation between city and nature in which the urban assumes many other different forms of diffusion on the territory.

What I would like to suggest in this text is that these phenomena - and the social movements that are to it associated - tend not to be so frequently connected to the analysis of turistification because they are more often considered the prerogative of a different analytical approach and of one different tradition of political thought: they are considered as "environmental conflicts" and studied with the categories of political ecology.

Political ecologist Martinez-Alier has coined the expression "ecology of the poor" (Martinez-Alier 2002) exactly to define the field of study of political ecology as the one concerning communities and territories fighting against extractivism, instead of a certain ecological 'Bourgeois' sensitivity founded on the idea of the defense of nature and perfectly non-contradictory with the so-called green capitalism. Most of his studies on extractivism have been based of research in Latin America, within the same debate from which it also derives the setting of tourism studies we have talked about so far.

However, at a later stage of his research, Martinez-Alier took part in a project of mapping of environmental conflicts in which he dealt with the European territory.

I refer here to the project 'Atlas of Environmental Justice' of 'Environmental Justice Organizations, Liabilities and Trade.' 5 This project aims to create a platform digital

\footnotetext{
${ }^{5}$ The Environmental Justice Organizations, Liabilities and Trade (www.ejolt.org) is a global research
} 
mapping of global "conflicts for environmental justice and ecological distribution", with many main thematic areas - nuclear, mining extractive, waste business, justice climatic conditions are some examples.

The work coordinated by Martinez-Alier on Europe has highlighted a new category of environmental conflicts that had not previously been foreseen, or that of connected conflicts to tourism. This category has been added to the map search filters, giving rise, in the case of the European continent, to the result we can see in Fig. $1^{6}$ : the environmental conflicts against tourism facilities cover the maritime cost of Mediterranean Europe.

Figure 1. Environmental justice atlas

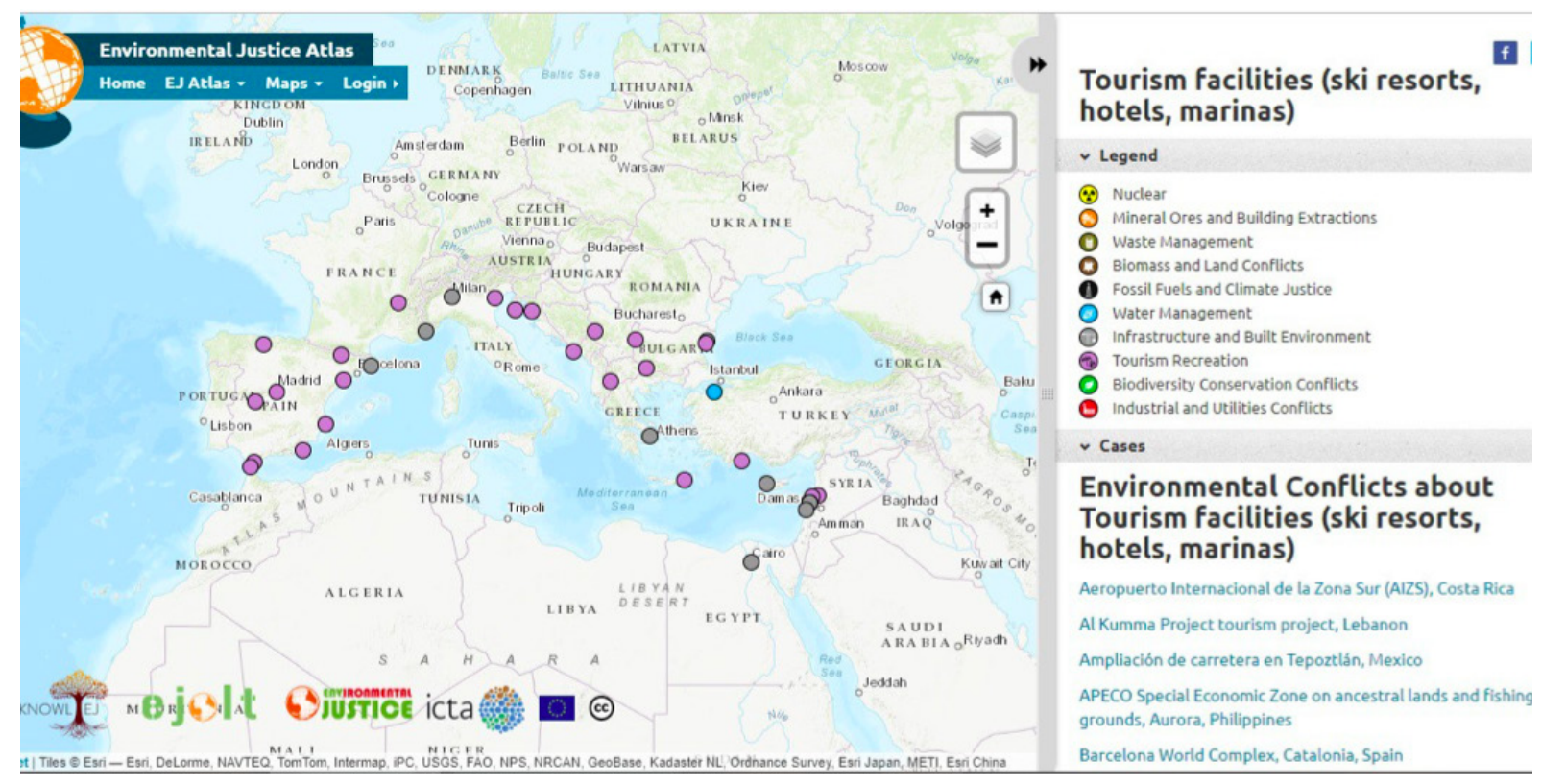

\section{CONCLUSION}

What I would like to highlight is the way in which the issue of touristification and that of environmental conflicts in the South of Europe encounter a space of strong coexistence and partial overlap within a dynamic of capitalist development of the territory that in both cases we can define extractive and responsive to a colonial rationality.

However, the two literatures intersect relatively little, being the question of tour-

project bringing science and society together to catalogue and analyze ecological distribution conflicts and confront environmental injustice. The primary objectives of EJOLT is to compile and make available an Atlas of Environmental Justice (https://ejatlas.org/). The Atlas of Environmental Justice is a practical and intuitive online platform that allows searching and filtering across 100 fields, as well as browsing by commodity, company, and type of conflict. The intellectual propriety of the maps and of all the images is of PROYECTO EJATLAS, INSTITUTO DE CIENCIA Y TECNOLOGÍA AMBIENTAL (ICTA), UNIVERSIDAD AUTÓNOMA DE BARCELONA (UAB).

${ }^{6}$ The present image (Fig.1) is reproduced here without any commercial purpose and the intellectual propriety is not, in any case, to be considered transmitted to any other entity or subject, according with the conditions of access and utilization of the site (https://ejatlas.org/legal, Retrieved December 15, 2019). 
ism still very closely linked to the space of the city - and the right to the city - while that of the environmental conflicts are typical of the non-metropolitan space.

It seems useful here to refer to what is written by Wendy Wolford and Sara Keene, by the way of the difficulty of applying political ecology to the study of the so-called 'social movements.'

What is claimed by the two authors is that there is a substantial disconnect between what is considered as 'environmental conflict' and what, instead, falls within the definition of 'social movemen.' This stems from a number of historical reasons, including the fact that the articulation between environmental conflicts and class has not always been linear.

Political ecology, however, interprets environmental conflicts exactly from the point of view of a community fighting for the territories, not a moral attitude to environmental conservation carried out by those who have the material conditions to be able to afford it.

This could be a useful perspective to re-read many of the contemporary phenomena of touristification, especially in the Southern Europe area? My hypothesis is that this kind of perspective could help us to force the foundational contradiction of turistification, or that between consumption of the territory - as an exhaustible asset - and 'conservation' of the same in a re-proposition equal to itself of a simple performance that has nothing to do with the territory as living tissue.

This, however, would imply a rethinking of the centrality of the urban space in relation to the tourist phenomenon and a different attention to urban spaces of another type; this passage, perhaps, implies a de-colonization of the categories and disciplines with which the question has so far been addressed.

FUNDING: This research received no external funding.

CONFLICT OF INTEREST: The author declares no conflict of interest.

ACKNOWLEDGEMENTS: The author acknowledges the support of to the Portuguese Science and Technology Foundation (FCT) through PD/BD/142794/2018 scholarship.

The author wishes also to acknowledge the contribution of dr. Francesco Biagi, Dr. Giacomo Salerno and Roberto Sciarelli in the process of bibliographical review.

\section{REFERENCES}

Brenner, Neil, Peter Marcuse, \& Margit Mayer, eds. 2012. Cities for people, not for profit. Critical urban theory and the right to the city. New York: Routledge.

Crick, Malcolm. 1989. "Representation of international tourism in the social sciences: Sun, Sex, Sights, Savings, and Servility.” Annual Review of Anthropology 18: 307344.

Cronan, William. 1991. Nature's Metropolis: Chicago and the Great West. New York: W. W. Norton \& Company. 
Environmental Justice Organizations, Liabilities and Trade. 2019. “Atlas of Environmental Justice.” Retrieved December 15, 2019 (https://ejatlas.org).

Ervedosa, Clara. 2017. "The Calibanisation of the South in the German Public 'Euro Crisis’ Discourse." Journal of Postcolonial Studies 20: 1-26.

Kearns, Gerry \& Chris Philo. 1993. Selling Places: The City as Cultural Capital, Past and Present (Policy Planning and Critical Theory). Oxford: Pergamon Press.

Gago, Veronica. 2015. La razón neoliberal. Madrid: Traficantes de Sueños.

Gago, Veronica and Sandro Mezzadra. 2015. "Para una crítica de las operaciones extractivas del capital. Patrón de acumulación y luchas sociales en el tiempo de la financiarización.” Nueva Sociedad 255: 38-52.

Gainsforth, Sarah. 2019. Airbnb città merce. Storie di resistenza alla gentrificazione digitale. Roma: DeriveApprodi.

Gorz, André. 2003. L’immateriale. Conoscenza valore e capitale. Torino: Bollati Boringhieri.

Harvey, David. 1989 The Condition of Postmodernity: An Enquiry into the Origins of Cultural Change. Oxford: Blackwell Publishing. 2012. Rebel Cities: From the Right to the City to the Urban Revolution. London-New York: Verso books.

Lefebvre, Henri. 1968. Le droit à la ville. Paris: Anthropos.

----- 1970. La révolution urbaine. Paris: Gallimard.

----- 1974. La production de l'éspace. Paris: Anthropos.

Martinez Alier, James. 2002. The environmentalism of the poor. A Study of Ecological Conflicts and Valuation. Cheltenham: Edward Elgar Pub.

Mellino, Miguel. 2014. David Harvey e l'accumulazione per espropriazione. Qualche considerazione su un'espressione equivoca. Euronomade.info, Retrieved December 15, 2019 (http://www.euronomade.info/?p=3244).

Mezzadra, Sandro. 2008. La condizione postcoloniale. Storia e politica nel presente globale. Verona: Ombre Corte.

Mezzadra, Sandro \& Brett Neilson. 2013. “Extraction, Logistics, Finance. Global Crisis and the Politics of Operations." Radical Philosophy 178: 8-18.

Mbembe, Achille. 2003. “Necropolitics.” Public Culture 15(1): 11-40.

Negri, Antonio \& Michael Hardt. 2009. Commonwealth. Harvard: Harvard University Press.

Said, Edward. 1978. Orientalism. New York: Pantheon.

Salerno, Giacomo M. 2018. "Estrattivismo contro il comune. Venezia e l'economia turistica.” ACME: An International Journal for Critical Geographies 17(2): 480-505.

Sousa Santos de, Boaventura. 2007. "Beyond Abyssal Thinking: From Global Lines to Ecologies of Knowledges.” Review (Fernand Braudel Center) 30(1): 45-89.

Visentin, Stefano. 2013. “Trasformazioni della Verwandlung. Rileggere l'accumulazione originaria attraverso Fanon.” Pp. n.p. in Fanon postcoloniale, edited by Mellino. Verona: Ombre corte.

Walker, Richard. 2008. The Country in the City: The Greening of the San Francisco Bay Area. Washington: University of Washington Press.

Wolford, Wendy \& Sarah Keene. 2015. "Social Movement.” Pp. 573-584 in The Rou- 
tledge Handbook of Political Ecology, edited by Tom Perreault, Gavin Bridge, \& James McCarthy. Abingdon, UK and New York: Routledge.

Zibechi, Raul. 2016. La nuova corsa all'oro. Società estrattiviste e rapina. Bologna: Mutus Liber.

\section{BIOGRAPHICAL NOTE}

Carla Panico is a PhD candidate in Postcolonialism and Global Citizenship at CES - Centre for Social Studies of the University of Coimbra - and a FCT scholarship holder. She is a member of ITM - Inter-thematic Group on Migrations and she is part of the organizing and scientific committee of the " 2020 . Migrating Rights | Keywords" series. She holds a Master's Degree in Contemporary History from University of Pisa - Italy. Her research interests include migrations, nationalism, whiteness and new social movements in Southern Europe, i.e. in contemporary Italy. She is currently a collaborator of the international research network Compoliticas for the project "Cibermov - Cyberactivism, Digital Citizenship and New Urban Movements" and a visiting fellow in the research project" De(othering) (CES - Portugal). She is a member of the "Societá italiana delle Storiche" - Italian Research Society of Women History.

OPEN ACCESS: This article is distributed under the terms of the Creative Commons Attribution Non-commercial License (CC BY-NC 4.0) which permits any non-commercial use, and reproduction in any medium, provided the original author(s) and source are credited.

ARTICLE HISTORY: Received 2020-03-25 / Accepted 2020-11-30 
